\title{
Antifungal and antitermitic activities of wood vinegar from oil palm trunk
}

\author{
Hasan Ashari Oramahi ${ }^{1} \cdot$ Tsuyoshi Yoshimura $^{2} \cdot$ Farah Diba $^{1} \cdot$ Dina Setyawati $^{1} \cdot$ Nurhaida $^{1}$
}

Received: 1 September 2017 / Accepted: 20 January 2018 / Published online: 16 February 2018

(c) The Japan Wood Research Society 2018

\begin{abstract}
We evaluated the antifungal and antitermite activities of wood vinegars produced from oil palm trunk. The wood vinegars were produced at three different pyrolysis temperatures, 350,400 , and $450{ }^{\circ} \mathrm{C}$. Antifungal activities of vinegars were evaluated using a Petri dish bioassay with $0.5,1.0$, and $1.5 \%$ (v/v) against a white-rot fungus, Trametes versicolor, and a brownrot fungus, Fomitopsis palustris. Antitermite activities were tested using a no-choice bioassay method for Coptotermes formosanus with 2.5, 5.0, 7.5, and $10.0 \%(\mathrm{v} / \mathrm{v})$. All the wood vinegars exhibited antifungal activities against $T$. versicolor. In particular, the wood vinegar produced at $350{ }^{\circ} \mathrm{C}$ resulted in complete inhibition of $T$. versicolor growth at 1.0 and $1.5 \%$. However, higher concentrations were required to obtain growth inhibition of $F$. palustris. All the wood vinegars exhibited antitermite activity to $C$. formosanus workers in the no-choice experiment at relatively high concentrations. For instance, $10 \%$ concentration was required to achieve $100 \%$ mortality against $C$. formosanus at all production temperatures. The lowest mass loss of the treated filter paper of $11.75 \%$ was obtained with a $350{ }^{\circ} \mathrm{C}-10.0 \%$ combination.
\end{abstract}

Keywords Wood vinegar $\cdot$ Oil palm trunk $\cdot$ Antifungal activity $\cdot$ Antitermite activity

\section{Introduction}

Wood and wood products are susceptible to biological degradation by fungi and termites. Synthetic chemicals have long been used to protect wood and wood products [1-3]; however, the problems associated with their use include the development of resistance by many pests, and the adverse negative effect to human health and the environment $[4,5]$. In addition, synthetic chemicals are produced from unrenewable materials. Therefore, the development of alternative bio-renewable and abundant materials is needed to find alternative wood preservative. One such alternative is wood vinegar.

Wood vinegars prepared from various sources of wood and wood-based composites have been tested for their effectiveness against decay fungi and insects [5-10]. For example, vinegars obtained from wood-based composites have

Hasan Ashari Oramahi

oramahi_stp@yahoo.com; oramahi@fahutan.untan.ac.id

1 Faculty of Forestry, Tanjungpura University, Pontianak, Indonesia

2 Research Institute for Sustainable Humanosphere (RISH), Kyoto University, Uji, Kyoto 611-0011, Japan been shown to have inhibitory effects against decay fungi [8]. Bedtmutha et al. [5] reported the insecticidal activity of wood vinegars produced at $400-600{ }^{\circ} \mathrm{C}$ against Colorado potato beetle (Leptinotarsa decemlineata Say). Hossain et al. [10] tested the insecticidal activity of wood vinegars derived from fast pyrolysis of lignin, cellulose, and hemicellulose at 450 and $550{ }^{\circ} \mathrm{C}$, and found that they were toxic at both temperatures against $L$. decemlineata, Trichoplusia $n i$, and Acyrthosiphon pisum.

Recently, Theapparat et al. [3] reported that wood vinegars exhibited antifungal activity against two white-rot fungi, a brown-rot fungus and a sapstain fungus. The vinegars were made from Eucalyptus camaldulensis, Leucaena leucocephala, Azadirachta indica, Hevea brasiliensis (rubberwood), and Dendrocalamus asper (bamboo). The largest component in the five wood vinegars that exhibited high fungicidal activities, especially in those made from rubberwood and bamboo, was total phenol. A previous study suggested that phenolic compounds derived from lignocellulosic biomass might be primarily responsible for the antifungal performance of wood vinegars [11]. Tar oil from macadamia nut shells was employed in vitro to protect wood against various wood-decaying fungi and wood-attacking termites [12]. 
Meanwhile, wood vinegar made from Cerbera odollam Gaertn produced at 300,400 , and $500{ }^{\circ} \mathrm{C}$ exhibited antitermite activity to Coptotermes formosanus in vitro [13]. Temiz et al. [14] investigated the termiticidal activity of a wood vinegar made from giant cane (Arundo donax L.), and found abundant components including acids, ketones, furans, benzenes, phenols, sugars, and guaiacols. They reported that the wood vinegar was effective against Reticulitermes flavipes. Shiny and Remadewi [15] reported that wood vinegar from shell oil had the potential to replace synthetic chemicals as a promising new biodegradable termiticide.

To the best of our knowledge, however, the antifungal and antitermite activities of wood vinegars made from oil palm trunk have not yet been reported. Oil palm plantations are spreading rapidly throughout Indonesia, resulting in substantial residues (i.e., felled oil palm trunk), because oil palm trees must be replaced at 25 year intervals [16]. In other words, oil palm trunk is an important agricultural wastes in Southeast Asia, and can be obtained at any of the plantation areas in Malaysia and Indonesia [17].

In this study, three wood vinegars obtained from oil palm trunk were examined for their antifungal activity against a brown-rot fungus, Fomitopsis palustris and a white-rot fungus, Trametes versicolor. The efficacy of the wood vinegars against an economically important termite, C. formosanus, was also evaluated.

\section{Materials and methods}

\section{Preparation and pyrolysis of oil palm trunk}

An oil palm trunk was collected at Bumi Pratama Khatulistiwa (BPK) Ltd. Mempawah Regency, West Kalimantan, Indonesia, and was converted into wood meal (20 meshpass) with a disk mill (Model FFC-23, Qingdao Dahua Double Circle Macheney, China). The wood meal was then air-dried to approximately $12 \%$ moisture content, and dried meal was pyrolyzed in a laboratory furnace, following Tranggono et al. [18] at pyrolysis temperature of 350,400 , and $450{ }^{\circ} \mathrm{C}$, respectively. The each pyrolysis temperature was repeated with three replicates. Smoke emitted from the reactor was channeled into a cooling column through the pipeline, and cold water was then flowed into the column [18]. This pyrolysis process was conducted in the Laboratory of Agriculture Engineering, Agriculture Faculty, Gadjah Mada University, Yogyakarta, Indonesia.

\section{Identification of wood vinegar by GC-MS}

Components in the three wood vinegars were analyzed with a gas chromatography-mass spectrometry (GC-MS) system (QP-210S, Shimadzu Manufacturing, Kyoto, Japan).
The analysis was conducted under the following conditions: Stabilwax-DA Columns (fused silica) capillary columns, $30 \mathrm{~m} \times 0.25 \mathrm{~mm}$; injection temperature: $225{ }^{\circ} \mathrm{C}$; column temperature program: $50-225^{\circ} \mathrm{C}$ increasing at $10^{\circ} \mathrm{C} / \mathrm{min}$; and He flow rate: $88.3 \mathrm{~mL} / \mathrm{min}$. The GC-MS was operated in the electron ionization mode at $70 \mathrm{eV}$ with an interface temperature of $225^{\circ} \mathrm{C}$. The $1 \mu \mathrm{L}$ wood vinegar was injected into the column. The chemicals were identified by comparing the MS spectra with the standard library data [19]. The chemical compositions of wood vinegar were determined by the integrated peak areas.

\section{Determination of total phenol}

Total phenol content of wood vinegars was estimated by a colorimetric assay, using the method described by Senter et al. [20]. An aliquot of wood vinegar $(1 \mathrm{~mL})$ was diluted 1000 times with deionized water (DI), and $1 \mathrm{~mL}$ of the diluted sample was added to $5 \mathrm{ml} 2 \% \mathrm{Na}_{2} \mathrm{CO}_{3}$ solution. After $10 \mathrm{~min}, 0.5 \mathrm{~mL}$ of Folin-Ciocalteau suspension was added to the solution. The absorbance of the solution at $750 \mathrm{~nm}$ was measured using a UV-Vis spectrophotometer (Shimadzu 1601, Shimadzu Manufacturing, Kyoto, Japan). The total phenol content of each wood vinegar was calculated in comparison with that of pure phenol suspension. Total phenol analyses were repeated with three replicates.

\section{Determination of acid}

The acidity of the wood vinegar was analyzed using the AOAC method [21]. $1 \mathrm{~mL}$ of the wood vinegar was diluted to $100 \mathrm{~mL}$ with DI, and then, three drops of the phenolphthalein indicator were added. The solution was titrated by $0.1 \mathrm{~N} \mathrm{NaOH}$. Three replicated runs were performed for acid determination.

\section{Fungal inhibition bioassay}

The fungal inhibition bioassay was performed according to Kartal et al. [22] and Kartal et al. [12]. Seven-day cultures of a brown-rot fungus, F. palustris (Berk. et Curt.) Gilb. \& Ryv. and a white-rot fungus, T. versicolor (L. ex Fr.) Quel. were grown on potato dextrose agar (PDA) plates at $27^{\circ} \mathrm{C}$ and used as inoculates. PDA media with $0.5,1.0$, and $1.5 \%(\mathrm{v} / \mathrm{v})$ wood vinegars were autoclaved for $15 \mathrm{~min}$ at $121^{\circ} \mathrm{C}$ and $103.4 \mathrm{kPa}$ (15 psi), and then poured into Petri dishes ( $90 \mathrm{~mm}$ diameter). There was no significance change of components of the wood vinegars during sterilization in autoclave. After cooling, the Petri dishes were centrally inoculated with a single plug $(5 \mathrm{~mm}$ diameter) from the pre-cultured PDA plates. Uninoculated PDA dishes were used as controls. Three replicates were conducted for each condition. The treated and control dishes were incubated in a conditioning room at $27^{\circ} \mathrm{C}$ until the growth of 
fungi in controls reached the edge of the dishes. The colony diameter was measured daily, and the percentage mycelia inhibition rate was calculated by the following equation:

$I=[(C-T) / \mathrm{C}] 100$

where $I=$ inhibition, as a percentage; $C=$ colony diameter of mycelium from control Petri dishes (mm); and $T=$ colony diameter of mycelium from the Petri dishes containing the wood vinegars $(\mathrm{mm})$.

\section{Antitermite test}

Mature workers and soldiers of $C$. formosanus were obtained from a laboratory colony at the Deterioration Organisms Laboratory (DOL), Research Institute for Sustainable Humanosphere (RISH), Kyoto University. The no-choice bioassay method was performed described by Kang et al. [23] and Ganapaty et al. [24]. DI-diluted wood vinegars $(0.3 \mathrm{ml})$ with concentrations of $0,2.5,5.0,7.5$, and $10.0 \%(\mathrm{v} / \mathrm{v})$ were pipetted onto filter papers (Whatman No. 1, $55 \mathrm{~mm}$ diameter). The treated filter paper was placed into a Petri dish $(60 \mathrm{~mm}$ in diameter), and 50 workers and 5 soldiers were placed on each filter paper. Filter papers treated with DI were used as controls. Test dishes were then covered and placed in an incubator maintained at $26.5{ }^{\circ} \mathrm{C}$ and $80 \% \mathrm{RH}$ in the dark. Three replicates were made for each concentration, and the mortalities of the termites were counted daily for 21 days. The mortality of worker and soldier of termites was count and we did not separately count the mortality of each worker and each soldier due to fasten on observations to avoid on disturb the termites activity.

\section{Statistical analysis}

A $3 \times 4$ and $3 \times 5$ factorial completely randomized design were used for antifungal and antitermite activities, respectively. The first factor was pyrolysis temperature: 350,400 , or $450{ }^{\circ} \mathrm{C}$ for both antifungal and antitermite activities. The second factor was concentration: $0,0.5,1.0$, and $1.5 \%(\mathrm{v} / \mathrm{v})$ for antifungal activity, and 0, 2.5, 5.0, 7.5, and 10.0\% (v/v) for antitermite activity. The means were separated using Duncan's multiple range test at $p=0.05$ for antifungal and antitermite activities, whereas for total phenol and acid, the means were separated using Tukey's test at $p=0.05$. All data were analyzed using the SAS software (version 8.2, SAS Institute Inc., NC, USA).

\section{Results and discussion}

\section{Wood vinegar properties}

The relative percentages of compounds identified by GC-MS in the wood vinegars at pyrolysis temperatures of
350,400 , and $450{ }^{\circ} \mathrm{C}$ are summarized in Table 1 . The major components of wood vinegar were achieved on different retention times due to difference of pyrolysis temperatures. The temperature of pyrolysis affected the degradation of wood chemical compound and resulted different amounts of each compound in wood vinegar. Similar to this result Theapparat et al. [3] stated the temperature of pyrolysis on wood made different retention times on GC-MS analysis. Overall, predominant compounds in wood vinegars were 1-hydroxypropanone, 3-hydroxy-2-butanone, acetic acid, propanoic acid, and phenol. This compound has the higher peak on the graphic of GC-MS analysis. All of the compounds were found in wood vinegar with pyrolysis time $350{ }^{\circ} \mathrm{C}$; meanwhile, in wood vinegar with pyrolysis time 400 and $450{ }^{\circ} \mathrm{C}$, only three compounds found, namely, 1-hydroxy2-propanone, acetic acid, and phenol. These five compounds were bioactive to inhibit the growth of fungi. Their relative percentage quantities in wood vinegar were dominant due to that they have higher peak on GC-MS analysis. A previous study reported that major compounds detected by GC-MS analyses of wood vinegars were organic acid and phenolic compounds such as phenol, cresol, guaiacol, eugenol, and syringol [25].

Table 2 lists the total phenol and total acid content in the wood vinegars. Total phenol and total acid contents ranged from 2.88 to $3.22 \%$ and 3.63 to $4.38 \%$, respectively. As shown in Table 2, total phenol in the wood vinegar prepared at $350{ }^{\circ} \mathrm{C}$ was significantly higher than those prepared at 400 and $450{ }^{\circ} \mathrm{C}$. Similar results were found in the previous studies, where the total phenol was the largest component in wood vinegar from walnut shell and pineapple plant waste biomass [26, 27]. Choi et al. [28] found that the main phenolic compounds were simple phenols, such as phenol, cresols, and 1,2-benzenediol, which were derived from the thermal decomposition of lignin. Ma et al. [26] and Wu et al. [29] previously reported the detailed chemical analysis of wood vinegar. Wu et al. [29] analyzed wood vinegars made from three agricultural and forestry residue samples, Chinese fir sawdust, cotton stalk, and bamboo sawdust, and found that the main compounds were acids, phenols, and ketones. Mathew et al. [27] identified 48 compounds by

Table 1 Relative percentage quantities of compounds identified by GC-MS in the wood vinegars with different pyrolysis temperatures

\begin{tabular}{lcll}
\hline Compound of wood vinegar (\%) & \multicolumn{3}{c}{ Pyrolysis temperatures } \\
\cline { 2 - 4 } & $350{ }^{\circ} \mathrm{C}$ & $400{ }^{\circ} \mathrm{C}$ & $450{ }^{\circ} \mathrm{C}$ \\
\hline 1-Hydroxy-2-propanone & 1.38 & 2.42 & 2.45 \\
Acetic acid & 71.89 & 63.19 & 9.15 \\
3-Hydroxy-2-butanone & 1.26 & - & - \\
Propanoic acid & 3.70 & - & - \\
Phenol & 21.77 & 34.40 & 88.40 \\
\hline
\end{tabular}


Table 2 Total phenol and acid concentrations in wood vinegars

\begin{tabular}{lll}
\hline Wood vinegar & Total phenol $(\%)^{\mathrm{a}}$ & Total acid $(\%)^{\mathrm{a}}$ \\
\hline W1 & $3.22 \pm 0.00 \mathrm{~A}$ & $4.38 \pm 0.02 \mathrm{~A}$ \\
W2 & $2.98 \pm 0.01 \mathrm{~B}$ & $4.35 \pm 0.02 \mathrm{~A}$ \\
W3 & $2.88 \pm 0.02 \mathrm{C}$ & $3.63 \pm 0.03 \mathrm{~B}$ \\
\hline
\end{tabular}

Numbers followed by letters $(\mathrm{A}-\mathrm{C})$ are significantly different at the level of $p<0.05$ according to Tukey's test

$W 1$ wood vinegar produced at $350{ }^{\circ} \mathrm{C}, W 2$ wood vinegar produced at $400{ }^{\circ} \mathrm{C}, W 3$ wood vinegar produced at $450{ }^{\circ} \mathrm{C}$

${ }^{\mathrm{a}}$ Means $(n=3) \pm \mathrm{SD}$

GC-MS analysis of wood vinegar. In that study, phenols (69.5\%), alkyl arylethers (9.33\%), and ketones $(7.76 \%)$ were the major constituents, while furan and pyran derivatives (3.57\%), sugar derivatives $(2.85 \%)$, organic acids $(2.67 \%)$, esters $(1.81 \%)$, aldehydes $(1.05 \%)$, alcohols $(0.9 \%)$, and nitrogenous compounds $(0.14 \%)$ were minor constituents.

$\mathrm{Wu}$ et al. [29] indicated that acetic and propionic acid were the major compounds in the acids, with acetic acid being dominant. Total acid content decreased as temperature was raised from 350 to $450{ }^{\circ} \mathrm{C}$. Similarly, in the case of pyrolysis products of palm kernel shells [28], it was indicated that the acids in wood vinegars actively participated in the condensation reaction at elevated temperatures. They reported composition of wood vinegar obtained under different reaction temperatures $\left(473-555^{\circ} \mathrm{C}\right)$. The major acid compounds produced by cellulose and hemicellulose degradations were acetic, hydroxyl-benzoic, and dodecanoic acid. Heo et al. [30] also found that chemical compounds such as acetic and benzoic acids were influenced by temperature.
These compounds rapidly increased with increasing temperature up to $500{ }^{\circ} \mathrm{C}$. In addition, when the temperature was increased, the acid content in wood vinegar decreased from 28.0 to $18.6 \mathrm{wt} \%$, while the water content increased from 34.2 to $48.0 \mathrm{wt} \%$ [28].

The chemical content of wood vinegar is affected by temperature and various other factors, including material size and proximate analysis (amount of cellulose, hemicellulose, lignin, volatile extractives, fixed carbon, and ash) in the samples [31, 32]. However, for the sake of practicality, we focused only on temperature in this research.

\section{Growth inhibition performance against decay fungi}

Table 3 shows percentage growth inhibition of the wood vinegars against decay fungi at concentrations from 0.5 to $1.5 \%(\mathrm{v} / \mathrm{v})$. All the wood vinegars showed antifungal activity, and performance increased with concentration in both fungi. The wood vinegar at $350{ }^{\circ} \mathrm{C}$ showed the highest performance with $100 \%$ inhibition against the white-rot fungus, T. versicolor at 1.0 and $1.5 \%$.

The reason why the highest antifungal activity of wood vinegar against $T$. versicolor was produced at $350{ }^{\circ} \mathrm{C}$ might be the higher amount of total phenol and total acid (Table 2) together with the characteristic existence of 3-hydroxy-2-butanone and propanoic acid (Table 1). The antifungal performance of the wood vinegars was significantly higher in the white-rot fungus, T. versicolor than in the brown-rot fungus, F. palustris. Even at the highest concentration (1.5\%) of wood vinegar at $350{ }^{\circ} \mathrm{C}, \mathrm{F}$. palustris grew a bit $(87 \%$ inhibition). Similar results were reported by Theapparat et al. [3] and by Oramahi and Yoshimura [9].
Table 3 Growth inhibition performance of wood vinegars from oil palm trunk against Trametes versicolor and Fomitopsis palustris on the PDA media

\begin{tabular}{llrr}
\hline Treatment & & & Inhibition $(\%)^{\mathrm{a}}$ \\
\cline { 1 - 1 } Wood vinegar & Concentrations of wood vinegars in & T. versicolor & \multicolumn{1}{c}{ F. palustris } \\
& PDA media (\%) & & \\
\hline Control & 0.5 & $59.63 \pm 2.07 \mathrm{C}$ & $0.00 \pm 0.00 \mathrm{~A}$ \\
W1 & 1.0 & $100 \pm 0.00 \mathrm{E}$ & $47.04 \pm 2.80 \mathrm{E}$ \\
& 1.5 & $100 \pm 0.00 \mathrm{E}$ & $86.67 \pm 3.34 \mathrm{H}$ \\
& 0.5 & $28.15 \pm 0.57 \mathrm{~B}$ & $11.85 \pm 0.61 \mathrm{~B}$ \\
W2 & 1.0 & $63.70 \pm 3.76 \mathrm{C}$ & $28.89 \pm 1,11 \mathrm{C}$ \\
& 1.5 & $96.67 \pm 5.16 \mathrm{E}$ & $54.07 \pm 3.21 \mathrm{~F}$ \\
& 0.5 & $26.30 \pm 1.52 \mathrm{~B}$ & $1.85 \pm 3.21 \mathrm{~A}$ \\
W3 & 1.0 & $79.26 \pm 6.47 \mathrm{D}$ & $36.30 \pm 1.70 \mathrm{D}$ \\
& 1.5 & $100 \pm 0.00 \mathrm{E}$ & $61.85 \pm 0.64 \mathrm{G}$ \\
\hline
\end{tabular}

Numbers followed by different letters $(\mathrm{A}-\mathrm{H})$ are significantly different at the level of $p<0.05$ according to Duncan's multiple range test

$W 1$ wood vinegar produced at $350{ }^{\circ} \mathrm{C}, W 2$ wood vinegar produced at $400{ }^{\circ} \mathrm{C}, W 3$ wood vinegar produced at $450{ }^{\circ} \mathrm{C}$

${ }^{\mathrm{a}}$ Means $(n=3) \pm \mathrm{SD}$ 
Kose and Kartal [33] and Arango et al. [34] stated that some brown-rot fungi including $F$. palustris secrete oxalic acid and have the higher resistance against $\mathrm{Cu}$-based wood preservatives. In addition, white-rot fungi are more sensitive to natural chemicals extracted from white spruce (Picea glauca), jack pine (Pinus banksiana), and red pine (Pinus resinosa) cones such as pinosylvin, pinosylvin monomethyl ether, and pinosylvin dimethyl ether, and the extractives inhibited the growth of white-rot fungi (T. versicolor and Phanerochaete chrysosporium), but slightly stimulated the growth of brown-rot fungi (Neolentinus lepideus, Gloeophyllum trabeum, and Postia placenta) at the 1:1:1 mixture of these compounds [35]. The results of this work showed that the color around the fungal colony changed during the bioassay with $F$. palustris. It thus was assumed that lignin and phenolic compounds in wood vinegars were metabolized by F. palustris. Pandey and Nagveni [36] stated that the rate of degradation of brown-rot fungi is higher than white-rot fungi. The fungi T. versicolor has preference for lignin degradation, and resulted in the reduction on ratio of lignin/carbohydrate.

Theapparat et al. [3] examined the antifungal activity of wood vinegar from $H$. brasiliensis and $D$. asper against two white-rot fungi (T. versicolor and Rigidoporopsis amylospora) and a brown-rot fungus (G. trabeum), and found that both were effective as wood preservatives. Oramahi and Yoshimura [9] reported that wood vinegar from Vitex pubescens Vahl inhibited white-rot fungus, $T$. versicolor, and a brown-rot fungus, $F$. palustris. The phenol content of wood vinegar is also likely responsible for antifungal activity. Okutucu et al. [37] suggested the fungicidal activity of the phenolic content of wood vinegar from pistachio shell. Similarly, Kartal et al. [22] reported that phenolic compounds in wood vinegars could contribute to decay resistance and that among the wood vinegars made from acacia (Acacia mangium) at a pyrolysis temperature of $300{ }^{\circ} \mathrm{C}$, and from sugi (Cryptomeria japonica) at pyrolysis temperatures of 270 and $300{ }^{\circ} \mathrm{C}$, only the sugi wood vinegar at $270{ }^{\circ} \mathrm{C}$ showed growth inhibition against the white-rot fungus, $T$. versicolor, at $0.1 \%$ concentration. Shiny et al. [38] speculated that high phenolic content of wood vinegar from coconut shell might be the reason for its antifungal activity. These results are in good agreement with our findings in the present study.

The wood vinegar in PDA medium has effective to inhibit the growth of $F$. palustris and T. versicolor. This might be due to inhibition of enzymatic activity by the compounds of the wood vinegars. Martinez et al. [39] stated that white-rot fungi have extracellular oxidative enzymes (oxidoreductases) and involved in degradation on cell wall component. Machuca and Ferraz [40] reported that the brown-rot fungi and white-rot fungi produced hydrolytic activities and this enzyme has a main function on degradation of the chemical components in wood. These enzymes on hydrolytic activities consist of xylanase and $\beta$-glucosidase. White-rot fungi were faster on decay process and need 30-60 days, while brownrot fungi need 120-150 days. Pandey and Nagveni [36] reported that degradation of wood structure by white-rot fungi caused both lignin and carbohydrate decrease; meanwhile, on wood attacked by brown-rot fungi, only the carbohydrate was reduced.

\section{Antitermite performance}

Mean percentage mass loss of the filter papers and mortalities of workers of $C$. formosanus are presented in Table 4. The mortalities were significantly increased with concentrations from 2.5 to $10 \%$ after 7,14 , and 21 days, and the filter papers treated with $10 \%$ solutions showed the highest mortalities in all the wood vinegars. The mass losses of filter papers after 21 days generally decreased with concentrations.

Termiticidal performance was consistent with concentration of total acid in the wood vinegars (Table 2), showing good agreement with the previous results. For example, Shiny and Remadewi [15] investigated the termiticidal activity of coconut shell oil against Odontotermes horni (Wasmann), O. obesus (Rambur), O. redamanni (Wasmann), and Microtermes obesi (Holmgren). They reported that the largest components in the coconut shell oil that exhibited high termiticidal performance were phenol or its highly oxygenated fractions. Temiz et al. [14] examined the termiticidal activity of wood vinegars, and stated that no mass losses were observed in treated samples, while untreated control samples showed $20 \%$ mass loss.

Sunarta et al. [41] concluded that wood vinegars made from oil palm fruit had the potential to be a low-cost and environmentally low-impact wood preservative for preventing attacks by Cryptotermes spp. Recently, wood vinegars from pineapple waste biomass were shown to have termiticidal activities against subterranean termites [42].

\section{Conclusions}

The wood vinegar from oil palm trunk produced at $350{ }^{\circ} \mathrm{C}$ completely inhibited the growth of the white-rot fungus, $T$. versicolor at 1.0 and $1.5 \%$ concentrations, whereas higher concentrations were required for the brown-rot fungus, $F$. palustris. The total phenol content of the vinegar produced at $350{ }^{\circ} \mathrm{C}$ was significantly higher than those of wood vinegars produced at 400 and $450{ }^{\circ} \mathrm{C}$. The wood vinegar produced at $350{ }^{\circ} \mathrm{C}$ has the potential to prevent attacks by $C$. formosanus. The practical evaluation of these wood vinegars as wood preservatives is worthy of consideration. 
Table 4 Termiticidal performance of wood vinegars from oil palm trunk against Coptotermes formosanus in a no-choice test with treated filter papers

\begin{tabular}{|c|c|c|c|c|c|}
\hline \multicolumn{2}{|l|}{ Treatment } & \multicolumn{3}{|c|}{ Termite mortality $(\%)^{\mathrm{a}}$} & \multirow[t]{2}{*}{ Mass loss after 21 days (\%) } \\
\hline Wood vinegar & $\begin{array}{l}\text { Conc. of treating } \\
\text { solutions }(\%)\end{array}$ & 7 days & 14 days & 21 days & \\
\hline Control & 0 & $0.0 \pm 0.0 \mathrm{~A}$ & $1.11 \pm 1.92 \mathrm{~A}$ & $1.11 \pm 1.92 \mathrm{~A}$ & $34.42 \pm 1.29 \mathrm{C}$ \\
\hline \multirow[t]{4}{*}{ W1 } & 2.5 & $2.22 \pm 3.85 \mathrm{~A}$ & $4.43 \pm 1.93 \mathrm{~A}$ & $5.55 \pm 3.85 \mathrm{~A}$ & $38.40 \pm 11.85 \mathrm{C}$ \\
\hline & 5.0 & $2.22 \pm 1.92 \mathrm{~A}$ & $3.33 \pm 0.0 \mathrm{~A}$ & $13.33 \pm 3.35 \mathrm{~A}$ & $31.93 \pm 6.02 \mathrm{C}$ \\
\hline & 7.5 & $74.44 \pm 7.70 \mathrm{C}$ & $86.67 \pm 5.77 \mathrm{CD}$ & $91.10 \pm 6.97 \mathrm{CD}$ & $27.96 \pm 2.40 \mathrm{BC}$ \\
\hline & 10.0 & $100 \pm 0.0 \mathrm{D}$ & $100 \pm 0.00 \mathrm{D}$ & $100 \pm 0.00 \mathrm{D}$ & $11.75 \pm 1.51 \mathrm{~A}$ \\
\hline \multirow[t]{4}{*}{ W2 } & 2.5 & $0.0 \pm 0.0 \mathrm{~A}$ & $2.22 \pm 3.85 \mathrm{~A}$ & $4.44 \pm 1.93 \mathrm{~A}$ & $33.54 \pm 10.47 \mathrm{C}$ \\
\hline & 5.0 & $1.11 \pm 1.92 \mathrm{~A}$ & $3.33 \pm 5.77 \mathrm{~A}$ & $8.87 \pm 7.68 \mathrm{~A}$ & $38.88 \pm 7.88 \mathrm{C}$ \\
\hline & 7.5 & $53.33 \pm 12.02 \mathrm{~B}$ & $66.67 \pm 10.0 \mathrm{~B}$ & $67.77 \pm 12.64 \mathrm{~B}$ & $28.27 \pm 4.70 \mathrm{BC}$ \\
\hline & 10.0 & $93.33 \pm 5.77 \mathrm{D}$ & $96.67 \pm 3.34 \mathrm{E}$ & $100 \pm 0.00 \mathrm{D}$ & $19.10 \pm 11.40 \mathrm{AB}$ \\
\hline \multirow[t]{4}{*}{ W3 } & 2.5 & $1.11 \pm 1.92 \mathrm{~A}$ & $1.11 \pm 1.92 \mathrm{~A}$ & $1.11 \pm 1.92 \mathrm{~A}$ & $31.22 \pm 1.33 \mathrm{C}$ \\
\hline & 5.0 & $3.33 \pm 3.34 \mathrm{~A}$ & $5.56 \pm 1.92 \mathrm{~A}$ & $5.56 \pm 1.92 \mathrm{~A}$ & $28.62 \pm 1.50 \mathrm{BC}$ \\
\hline & 7.5 & $78.89 \pm 19.24 \mathrm{C}$ & $81.11 \pm 18.36 \mathrm{C}$ & $81.11 \pm 18.36 \mathrm{C}$ & $28.78 \pm 4.88 \mathrm{BC}$ \\
\hline & 10.0 & $97.78 \pm 3.85 \mathrm{D}$ & $100 \pm 0.0 \mathrm{E}$ & $100 \pm 0.0 \mathrm{D}$ & $18.35 \pm 3.08 \mathrm{AB}$ \\
\hline
\end{tabular}

Numbers followed by different letters (A-H) are significantly different at the level of $p<0.05$ according to Duncan's multiple range test $W 1$ wood vinegar produced at $350{ }^{\circ} \mathrm{C}, W 2$ wood vinegar produced at $400{ }^{\circ} \mathrm{C}, W 3$ wood vinegar produced at $450{ }^{\circ} \mathrm{C}$

${ }^{a}$ Means $(n=3) \pm \mathrm{SD}$ using 55 termites per replicate

Acknowledgements The authors would like to thank the Directorate General of Higher Education of Indonesia for financially supporting this project in fiscal year 2013-2014, through a competitive research grant. We thank the Laboratory of Innovative Humano-habitability, RISH, Kyoto University, Japan, for providing experimental materials and facilities for this research.

\section{References}

1. Meyer JR (2005) Isoptera. Department of Entomology. NC State University. http://www.cals.ncsu.edu/course/ent425/compendium /termites.html. Accessed 10 Jan 2017

2. Verma M, Sharma S, Prasad R (2009) Biological alternatives for termite control: a review. Int Biodeterior Biodegradat 63:1-14

3. Theapparat Y, Chandumpai A, Leelasuphakul W, Laemsak N (2015) Pyroligneous acids from carbonisation of wood and bamboo: their components and antifungal activity. J Trop Forest Sci 27:517-526

4. Preston AF (2000) Wood preservation: trends of today that will influence the industry tomorrow. Forest Prod J 50:13-19

5. Bedmutha R, Booker CJ, Ferrante L, Briens C, Berruti F, Yeung KKC, Scott I, Conn K (2011) Insecticidal and bactericidal characteristics of the bio-oil from the fast pyrolysis of coffee grounds. J Anal Appl Pyrolysis 90:224-231

6. Yatagai M, Nishimoto M, Ohira KHT, Shibata A (2002) Termiticidal activity of wood vinegar, its components and their homologues. J Wood Sci 48:338-342

7. Mohan D, Shi J, Nicholas DD, Pittman CU Jr, Steele PH, Cooper JE (2008) Fungicidal values of bio-oils and their lignin-rich fractions obtained from wood/bark fast pyrolysis. Chemosphere 71:456-465

8. Nakai T, Kartal SN, Hata T, Imamura Y (2007) Chemical characterization of pyrolysis liquids of wood-based composites and evaluation of their bio-efficiency. Build Environ 42:1236-1241
9. Oramahi HA, Yoshimura T (2013) Antifungal and antitermitic activities of wood vinegar from Vitex pubescens Vahl. J Wood Sci 59:344-350

10. Hossain MM, Scott IM, McGarvey BD, Conn K, Ferrante L, Berruti $F$, Briens $C$ (2015) Insecticidal and anti-microbial activity of bio-oil derived from fast pyrolysis of lignin, cellulose, and hemicellulose. J Pest Sci 88:171-179

11. Kim KH, Jeong HS, Kim JY, Han GS, Choi IG, Choi JW (2012) Evaluation of the antifungal effects of bio-oil prepared with lignocellulosic biomass using fast pyrolysis technology. Chemosphere 89:688-693

12. Kartal SN, Terzi E, Kose C, Hofmeyr J, Imamura Y (2011) Efficacy of tar oil recovered during slow pyrolysis of macadamia nut shells. Int Biodeterior Biodegradat 65(2):369-373

13. Rosalina TT, Riani E, Sugiarti S (2016) An environmental friendly pesticide from bintaro (Cerbera odollam gaertn) liquid smoke for pine wood preservation against a subterranean termite Captotermes curvignathus Holmgren attack. Rasayan J Chem 9:438-443

14. Temiz A, Akbas S, Panov D, Terziev N, Alma MH, Parlak S, Kose $\mathrm{G}$ (2013) Chemical composition and efficiency of bio-oil obtained from giant cane (Arundo donax L.) as a wood preservative. Bioreseources 8:2084-2098

15. Shiny KS, Remadevi OK (2014) Evaluation of termiticidal activity of coconut shell oil and its comparison to commercial wood preservatives. Eur J Wood Wood Prod 72:139-141

16. H'ng PS, Chai LY, Chin KL, Tay PW, Eng HK, Wong SY, Wong WZ, Chow MJ, Chai EW (2013) Urea formaldehyde impregnated oil palm trunk as the core layer for three-layered board. Mater Des 50:457-462

17. Hansen SB, Padfield R, Syayuti K, Evers S, Zakariah Z, Mastura S (2015) Trends in global palm oil sustainability research. J Clean Prod 100:140-149

18. Tranggono S, Setiadji B, Darmadji P, Supranto S (1996) Identifikasi Asap Cair dari Berbagai Jenis Kayu dan Tempurung Kelapa (in Indonesia). J Ilmu dan Teknologi Pangan 1(2):15-24 
19. Mun SP, Ku CS (2010) Pyrolysis GC-MS analysis of tars formed during the aging of wood and bamboo crude vinegars. J Wood Sci $56: 47-52$

20. Senter SD, Robertson JA, Meredith FI (1989) Phenolic compound of the mesocarp of Cresthaven peaches during storage and ripening. J Food Sci 54:1259-1268

21. AOAC association of official analytical chemists (1990) Official methods of analysis. AOAC, Arlington

22. Kartal SN, Imamura Y, Tsuchiya F, Ohsato K (2004) Evaluation of fungicidal and termiticidal activities of hydrolysates from biomass slurry fuel production from wood. Bioresour Technol 95:41-47

23. Kang H-Y, Matsushima N, Sameshima K, Takamura N (1990) Termite resistance tests of hardwoods of Kochi growth. I. The strong termiticidal activity of kagonoki (Litsea coreana Leveille). Mokuzai Gakkaishi 36:78-84

24. Ganapaty S, Thomas PS, Fotso LH (2004) Antitermiic quinones from Diospyros sylvatica. Phytochemistry 65:1265-1271

25. Weerachanchai $\mathrm{P}$, Tangsathitkulchai $\mathrm{C}$, Tangsathitkulchai $\mathrm{M}$ (2011) Characterization of products from slow pyrolysis of palm kernel cake and cassava pulp residue. Korean J Chem Eng 28:2262-2274

26. Ma X, Wei Q, Zhang S, Shi L, Zhao Z (2011) Isolation and bioactivities of organic acids and phenols from walnut shell pyroligneous acid. J Anal Appl Pyrolysis 91:338-343

27. Mathew S, Zakaria ZA, Musa NF (2015) Antioxidant property and chemical profile of pyroligneous acid from pineapple plant waste biomass. Process Biochem 50:1985-1992

28. Choi GG, Oh SJ, Lee SJ, Kim JS (2015) Production of bio-based phenolic resin and activated carbon from bio-oil and biochar derived from fast pyrolysis of palm kernel shells. Bioresour Technol 178:99-107

29. Wu Q, Zhang S, Hou B, Zheng H, Deng W, Liu D, Tang W (2015) Study on the preparation of wood vinegar from biomass residues by carbonization process. Bioresour Technol 179:98-103

30. Heo HS, Park HJ, Park YK, Ryu C, Suh DJ, Suh YW, Yim JH, Kim SS (2010) Bio-oil production from fast pyrolysis of waste furniture sawdust in a fluidized bed. Bioresour Technol 101:S91-S96

31. Demiral İ, Ayan EA (2011) Pyrolysis of grape bagasse: effect of pyrolysis conditions on the product yields and characterization of the liquid product. Bioresour Technol 102:3946-3951
32. Abnisa F, Arami-Niya A, Wan Daud WMA, Sahu JN, Noor IM (2013) Utilization of oil palm tree residues to produce bio-oil and bio-char via pyrolysis. Energ Convers Manage 76:1073-1082

33. Kose C, Kartal SN (2010) Tolerance of brown-rot and dry-rot fungi to CCA and ACQ wood preservatives. Turk J Agric For 34:181-190

34. Arango RA, Lebow PK, Green F (2009) Correlation between oxalic acid production and tolerance of Tyromyces palustris strain TYP-6137 to N0,N-naphthaloylhydroxamine. Int Biodeterior Biodegradat 63:46-51

35. Celimene CC, Micales JA, Ferge L, Young RA (1999) Efficacy of pinosylvins agains white-rot and brown-rot fungi. Holzforschung 53:491-496

36. Pandey KK, Nagveni HC (2007) Rapid characterisation of brown and white rot degraded chir pine and rubberwood by FTIR spectroscopy. Eur J Wood Wood Prod 65(6):477-481

37. Okutucu C, Duman G, Ucar S, Yasa I, Yanik J (2011) Production of fungicidal oil and activated carbon from pistachio shell. J Anal Appl 91:140-146

38. Shiny KS, Remadevi OK, Wijayalakshmi G (2014) Preliminary study on antifungal of coconut shell pyrolytic oil against wood decay fungi. Int Wood Prod J 5:124-126

39. Martínez AT, Speranza M, Ruiz-Duenas FJ, Ferreira P, Camarero S, Guillen F, Martinez MJ, Gutiérrez A, Del Rio JC (2005) Biodegradation of lignocellulosics: microbial, chemical, and enzymatic aspects of the fungal attack of lignin. Int Microbiol 8:195-204

40. Machuca A, Ferraz A (2001) Hydrolytic and oxidative enzymes produced by white-and brown-rot fungi during Eucalyptus grandis decay in solid medium. Enzyme Microb Technol 29(6):386-391

41. Sunarta S, Darmadji P, Uehara T, Katoh S (2011) Production and characterization of palm fruit shell bio-oil for wood preservation. Forest Prod J 61:180-184

42. Yahayu M, Mahmud KN, Muhamad MN, Ngadiran S, Lipeh S, Ujang S, Zakaria ZA (2017) Efficacy of pyroligneous acid from pineapple waste biomass as wood preserving agent. Jurnal Teknologi 79:1-8 